\section{Effects Of Interactive Digital Media ON ArChitectural Heritage learning}

\author{
Juliana A. Abubakara*, Puteri Shireen Jahnkassimb, Murni Mahmudc \\ aschool of Multimedia Technology \& Communication, College of \\ Arts and Sciences, Universiti Utara Malaysia \\ bKulliyyah of Architecture \& Environmental Design International \\ Islamic University Malaysia \\ cKulliyyah of Information Communication Technology International \\ Islamic University Malaysia
}

Article history

Received

15 June 2015

Received in revised form

1 October 2015

Accepted

13 October 2015

*Corresponding author liana@uum.edu.my

\section{Graphical abstract}
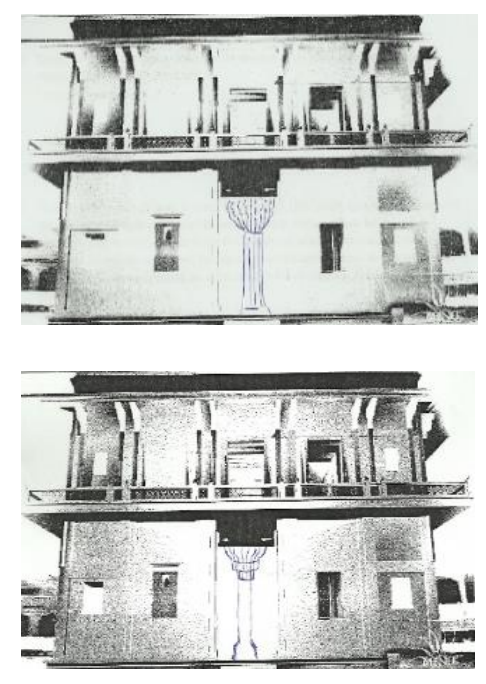

\begin{abstract}
This study attempts to determine the effects of three modes of digital media (virtual reality, video, and Web) on architectural heritage learning. It also aims to determine the demographics' effects of museum visitors on learning using interactive digital media. The content of these media focuses on historical and architectural information of a cultural heritage monument at a UNESCO World Heritage Site. This study has employed quasiexperimental method with the use of designated tasks and retention test in real-world setting. It is found that there is a significant difference among these digital media on retention score. Further analysis reveals that virtual reality provides the lowest retention score and contributes to this significant difference when compared to video. There is no significant difference between gender and retention score. However, there is a significant difference among age and retention score. This study contributes towards empirical evidence on the significant use of interactive digital media on architectural heritage learning and provides insights about demographic effects of interactive digital media on architectural heritage learning.
\end{abstract}

Keywords: Digital media, architectural heritage learning, virtual reality, video, Web

\section{Abstrak}

Kajian ini ingin menentukan kesan tiga mod media digital (realiti maya, video dan Web) ke atas pembelajaran warisan senibina. la juga ingin menentukan kesan demografi pengunjung muzium kepada pembelajaran menggunakan media digital interaktif. Kandungan mediamedia ini memfokus kepada maklumat senibina dan bersejarah sebuah monumen warisan budaya di Tapak Warisan Dunia UNESCO. Kajian ini melaksanakan metod kuasi-esperimen dengan penggunaan tugasan yang dibentuk dan ujian pengekalan dalam persekitaran sebenar. Hasil kajian mendapati terdapat perbezaan yang signifikan di antara media digital ini ke atas skor pengekalan. Analisis seterusnua mendedahkan bahawa realiti maya mempunyai skor paling rendah dan menyumbang kepada perbezaan yang signifikan apanila dibandingkan dengan video. Kajian ini juga mendapati tiada perbezaan yang signifikan di antara jantina dan skor pengekalan. Walau bagaimanapun, terdapat perbezaan yang signifikan di antara umur dan skor pengekalan. Kajian ini menyumbang kepada bukti empirikal ke atas pembelajaran warisan senibina melalui penggunaan media digital interaktif dan memberikan gambaran kesan media digital interaktif daripada segi demografi ke atas pembelajaran warisan senibina.

Kata kunci: Media digital, pembelajaran warisan senibina, reality maya, video, Web

(C) 2016 Penerbit UTM Press. All rights reserved 


\subsection{INTRODUCTION}

Looking into characteristics of informal education particularly in museums, there are diverse learning theories of informal learning and mental models that constituted learning in museum such as the contextual model of learning [1], the complex behaviour of visitors [2], and the significance of such studies to be embodied in overall museum experience [3]. In museum context, it is suggested that historical interpretation, storytelling, contextualizing objects, allowing artistic means of expression, and creating emotional response to visitors are keys to successful museum visits [4], [2].

Recent studies reveal that, in specific age of group, school children rated the interactive digital media of virtual reality (VR) higher than traditional teaching methods in terms of user experience [5] and there exists strong positive correlation between learning and immersion when using VR [6]. However, in another study using pervasive games for art history, there is no significant difference between interactive digital media and traditional interpretation methods [7]. Due to the complex nature of visitors' behaviour, the data collection is normally conducted by means of interviews [8], a mix of observation and questionnaire [9], and short-term memory retention and observation [3]. To date, there are also increasing attempts to evaluate interactive digital media in real-world setting using experimental design [7], [6].

These past studies have revealed that the use of interactive digital media is capable of providing elements of learning to museum visitors. However, little is known to what extent these digital media may contribute towards architectural heritage learning and is there any significant difference among these media on learning. Thus, this study attempts to determine the effects of three modes of digital media, which are high-interactive VR, passive video, and low-interactive web, on architectural heritage learning as well as to determine the demographics' effects of museum visitors on learning using these interactive digital media.

\subsection{RELATED WORK}

\subsection{Learning Architectural Aspects of Cultural Heritage Sites}

Cultural heritage sites may include architectural significance of monuments and structures that possess unique features and represent cultural identity of the nation. This is critical at this juncture not only to preserve and conserve these structures in the name of cultural heritage but also to disseminate cultural information behind these standing structures which normally intangible and not available on site. There perhaps restrictions on people or in this case tourists, to get physically on site due to dramatic erosion and pollution by tourists towards the cultural heritage sites which were already combatting their existence against time and nature [10]. When it comes to issues pertaining to learning architectural aspects of a cultural heritage site, three major points may be considered: whether the approach of displaying static photos and 3D miniature model of architectural significance in museums is attracting the young generation who relatively exposes to technology (motivation); whether we can feel as if we are in that heritage site (sense of presence), and whether we can recall historical information, if given, and recognise unique standing structure in that particular site (learning). The interface of any interactive media must be intuitive enough so that the learning process would take place uninterrupted [2], [8], [3].

\subsection{Demographics' Effects on Learning}

The attraction of interactive digital media in museums is appealing to children and young adults [11][2]. When it comes to learning, children was unable to capture facts and figure as fast as the young adults who learnt faster due to prior knowledge and adults have higher level of engagement while using interactive digital media [12]. Elderly, on the other hand, needs motivation, experience, and cognitive in order to pursue learning using interactive digital media [21].

For children, previous museum studies found VR is appealing to children [13], [4], [11], [14] and there is no significant difference between games and traditional interpretation methods on learning [6]. However, for all ages, a recent study in pervasive games shows that there exists strong positive correlation between learning and immersion when using virtual reality devices [7].

\subsection{METHODOLOGY}

In examining user behaviour while interacting with computers or computer-related devices, experimental research has the advantage of allowing the identification of causal relationship between entities or events [15]. On the other hand, difficulty of formulating testable hypothesis, controlling confounding factors, and changes in observed behaviour are notable limitations of experimental research. However, with its overall validity well-grounded, experimental research is able to provide critical analysis and generalizable findings through controlled experiments. Due to the difficulties of random assignment, the series of user evaluation employs a quasi-experiment using between-subject design where a participant is only exposed to one condition that is VR, video, or Web. This betweensubject design has the advantages over withinsubject design by means of avoiding learning effect on participant from different task conditions and shorter time for participant to complete the experiment [15], [22]. While it is rare to find user 
studies conducting experiment inside museums, it is believed that quasi-experimental approach [23][24] is the best way to gauge the information required by this study. Task performance is measured using number of completed tasks by means of user tasks [25]. Retention test is measured using the knowledge level of recall and recognition in Bloom's taxonomy of learning [26], [27].

The selected museum is a rebuilt of a royal palace and its exhibits are related to the history of the sultanate, the architectural models of past royal palaces in Malaysia, the functions of public audience hall, and the royal customs. The equipment for evaluation was setup inside the museum and in front of Balairung Seri (Hall of Public Audience) as illustrated in Figure 1.

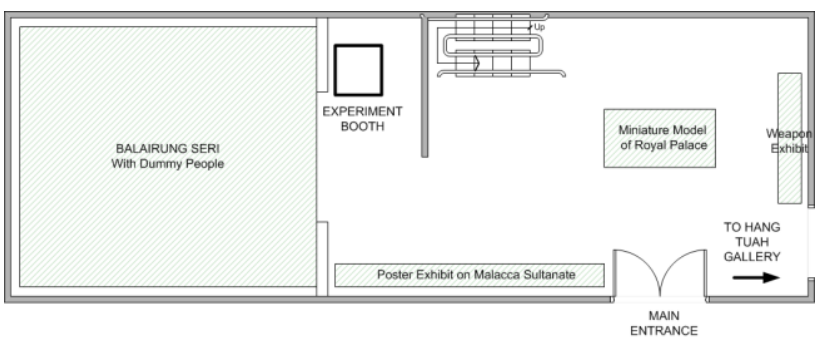

Figure 1 The evaluation setup at the Museum (not to scale)

The user evaluation was conducted during the operational hours of the respective museum in conjunction with Malaysian school holidays. It is anticipated that this museum receives relatively large amount of visitors during these period. Thus, this would help to draw as many visitors as possible to participate in this evaluation. This evaluation was conducted in an open space and participants were mainly families and young adults as shown in Figure 2 . The use of 20-inch flat screen has reduced the maximum size of group participants to four.
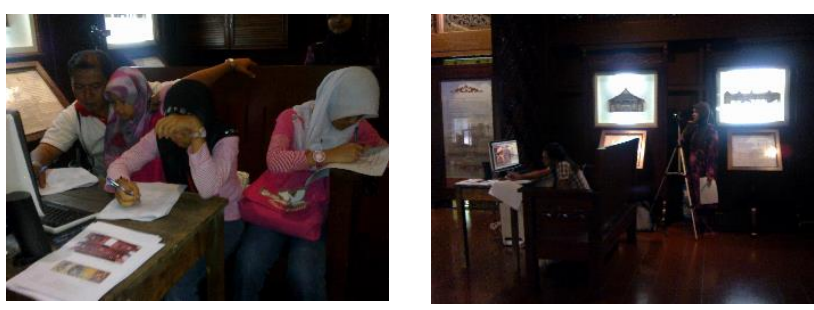

Figure 2 Evaluation in progress

The evaluation includes three groups of users whereby each group uses only one learning medium which was intended to provide historical and architectural heritage information. Those participants in groups were advised to alternately experience the VR, the Video and the Web among members. Each group is expected to undergo four phases to complete the evaluation. These phases were derived from previous studies that suggest the use of mixed methods of qualitative and quantitative approach to gather more comprehensive outcomes [2], [16], [8].

During the evaluation, at least two evaluators were there, one was to respond to respondents' enquiries and another was to mark time stamps and did the video recording. In most cases, respondents were free to use the digital media and complete the designated tasks themselves. Evaluators would help them only upon request and at critical incidents that halted respondents to complete their tasks [28].

Participants were targeted from the respective museum visitors during the operational hours of the day. Visitors were invited to participate in this study upon their informed consents, meaning that they volunteered to participate and may withdraw from the evaluation at any point of time without penalty [29]. Participants were briefed on the objectives and the expected outcome of the evaluation. Demographic information on age, gender, occupation, computer competency, VR experience, familiarity with $2 D$ and $3 D$ input devices as well the content of application was collected. Participants were then given five (5) minutes to be familiar with the digital media before doing the designated tasks. Each interactive digital media has different designated tasks to complete as described in the subsequent section. For example, for those using VR, the tasks are designed to allow participants walking around the monuments and appreciate the craftsmanship of structural elements. These would also help participants to discover necessary information for the retention test [29]. A small token of appreciation was given to participants upon completion. The designated time to complete the evaluation is 30 minutes. The Malay versions of the evaluation leaflet were also prepared and distributed upon participant request.

A pilot test was conducted prior to the experiment in order to validate the evaluation procedures and to collect feedback of the entire evaluation session [30]. The pilot test was administered using five (5) participants and was conducted away from the museum settings due to time and venue constraints. Results from the pilot test were used to enhance evaluation instruments and designated tasks. 


\subsection{RESULTS AND DISCUSSIONS}

\subsection{Demographics of Participants}

Table 1 shows the demographics of the participants. There were 90 participants involved in this evaluation. There was a balance number of female $(46,51.1 \%$ ) and male $(44,48.9 \%)$ participated in this evaluation. The largest group of age was from age 15 to 24 (56, $62.2 \%)$. Almost half of the participants (46\%) had their tertiary education which reasonably indicate their capabilities to understand the objective of the experiment and be better informed.

Table 1 Profile of participants $(\mathrm{N}=90)$

\begin{tabular}{clc}
\hline \multirow{2}{*}{ Item } & Classification & Frequency (\%) \\
\hline \multirow{2}{*}{ Gender } & Male & \\
& Female & $44(48.9)$ \\
Age & $<15$ & $46(51.1)$ \\
& $15-24$ & $16(17.8)$ \\
& 25 and above & $56(62.2)$ \\
Academic & Primary & $18(20.0)$ \\
Qualification & Secondary & $2(2.3)$ \\
& Tertiary & $30(34.5)$ \\
& Others & $40(46.0)$ \\
Computer & 0 to 1 year & $15(17.2)$ \\
Experience & 1 to 2 years & $10(11.1)$ \\
& 2 to 3 years & $8(8.9)$ \\
& More than 3 years & $67(5.6)$ \\
& & \\
Computer Use & Very often & $34(37.8)$ \\
& Often & $36(40.0)$ \\
& Rarely & $20(22.2)$ \\
\hline
\end{tabular}

\subsubsection{Familiarity with Input Devices}

Figure 3 shows the frequency analysis on participant's familiarity with input devices [31]. It is found that majority participants always use keyboard $(72,84.7 \%)$ and mouse $(67,78.8 \%)$. Only one participant (1.2\%) was reported never use keyboard and mouse and this participant was given a short training at the beginning of the evaluation.

It is also found that few participants always use touch screen $(24,28.2 \%)$, joystick $(19,22.4 \%)$ and stylus $(14,16.7 \%)$. Majority participants never use 3D mouse $(63,74.1 \%)$ and drawing tablet $(61,71.8 \%)$.

\subsubsection{Familiarity with the Content}

Table 2 shows that all participants have not been to the cultural heritage site mentioned and four (4) participants have heard of it. This suggests participants have limited knowledge on the content of the digital media. It is then assumed that they would depend on their short-term memory during the retention test [2], [3].

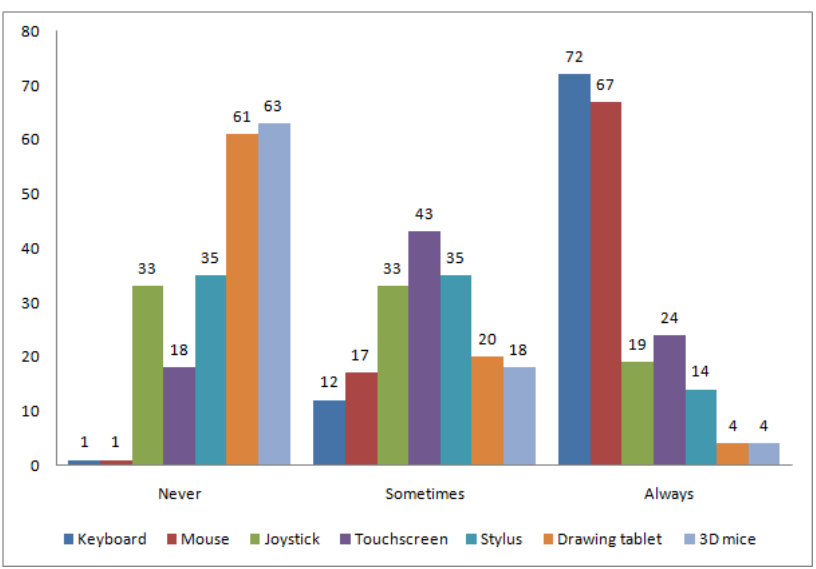

Figure 3 Frequency Analysis on Familiarity with Input Devices $(n=85)$

Table 2 Familiarity with content ( $N=90)$

\begin{tabular}{|c|c|c|}
\hline Item & Classification & Frequency (\%) \\
\hline Been to the place & $\begin{array}{l}\text { Yes } \\
\text { No }\end{array}$ & $\begin{array}{c}0(0) \\
90(100.0)\end{array}$ \\
\hline $\begin{array}{c}\text { Heard of the } \\
\text { place? }\end{array}$ & $\begin{array}{l}\text { Yes } \\
\text { No }\end{array}$ & $\begin{array}{c}4 \\
86\end{array}$ \\
\hline Where from?* & $\begin{array}{l}\text { Magazine/Books } \\
\text { Family/Friends }\end{array}$ & $\begin{array}{l}2 \\
2\end{array}$ \\
\hline
\end{tabular}

Four (4) participants have heard of the place from magazine or books (2) and from family or friends (2).

\subsubsection{Understanding of Virtual Heritage}

The understanding of virtual heritage may provide input on the background knowledge of the participants [32]. When asked on the definition of virtual heritage, 13 participants $(29 \%)$ understand about the term. 10 participants $(23 \%)$ more or less know but another $10(23 \%)$ have completely had no idea about the term. Seven participants (16\%) have not heard about virtual heritage and four participants (9\%) have heard but not sure of the definition.

Participants who understand the meanings of virtual heritage provide responses as the following:

1. P44: "learn history from computer/electronic devices",

2. P48: "understanding or learning heritage through virtual methods like machines or demonstrations", 
3. P60: "virtual heritage is an interesting way to let more people and students learn about history and architecture in interactive method",

4. P75: "the attempt to bring the experience of being to the historic places/ruins",

5. P74: "historical buildings/things which can be seen virtually",

6. P70: "learn the history through Website".

These responses suggest that participants associate virtual with interactive method while others generally refer the term virtual as computer/electronic devices or Web site. One believes the term virtual heritage is coupled with experience of being to the historic places or ruins.

Nevertheless, it can be concluded that only a small percentage of the participants familiar with the term virtual heritage $(29 \%)$ and have encountered VR applications (33.7\%). All participants have not been to the cultural heritage site and majority (95\%) have not heard of the cultural heritage site.

\subsection{Retention}

All answers obtained during the retention session were assessed. The marks were allocated for the drawings of structural elements based on its similarity with the real structure (base, pillar, and carved brackets of the central pillar). Two illustrations that resemble a missing central pillar are depicted in Figure 4.

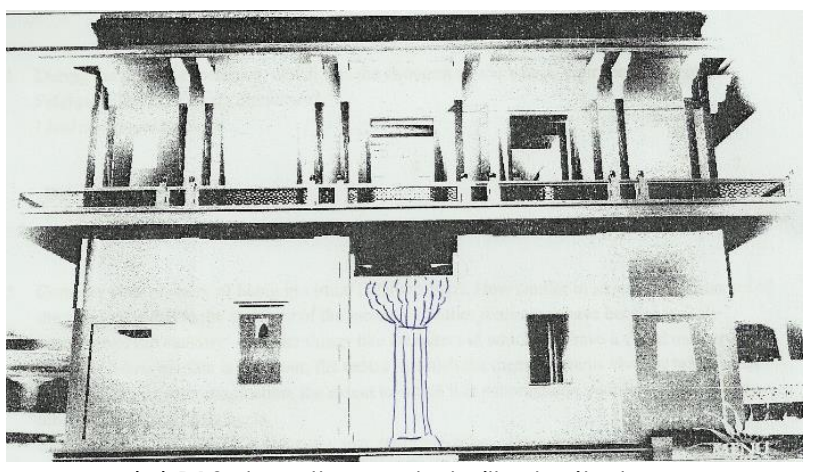

(a) P18 drew the central pillar by its shape

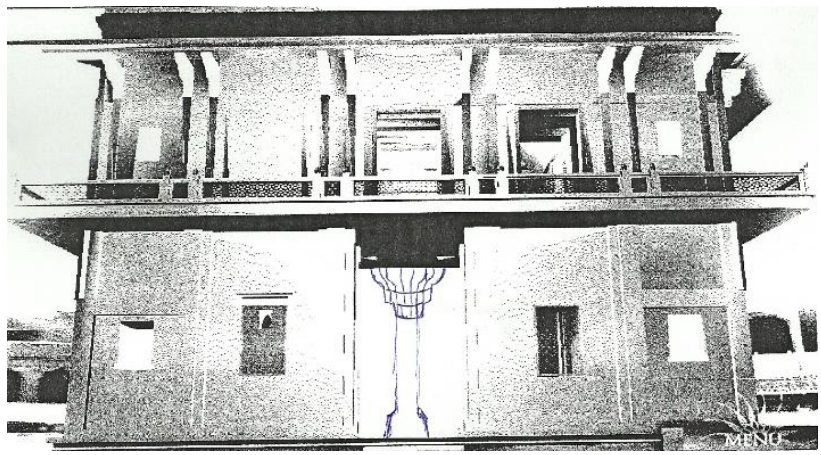

(b) P34 drew three structural elements of the central pillar

Figure 4 Drawing from VR retention test on a missing structure
A handful drew a similar shape of carved brackets grooming (some of them have cursive, some of them were mere square brackets) from central pillar to upper platform and lower column with simple ornamentation. There are also participants that only drew a straight pillar from ground to upper level or put the text 'pillar' at the location of the missing structure.

Using descriptive analysis as shown in Table 3 , it is found that those using Video has the highest mean score of 6.56. Those using Web scores second with the mean of 5.57. Those using $V R$ has the least mean score of 4.73 .

Table 3 Mean scores for retention and corresponding standard deviation

\begin{tabular}{ccc}
\hline Digital Media ( $\mathbf{n})$ & Mean & SD \\
\hline $\operatorname{VR}(40)$ & 4.73 & 1.935 \\
$\operatorname{Video~(25)}$ & 6.56 & 2.022 \\
Web (23) & 5.57 & 2.50 \\
\hline
\end{tabular}

One-way analysis of variance was conducted to determine the effect of each digital media to retention tests. The confidence interval used was $95 \%$ or 0.05. This analysis assumed that the group variances are equal as $p>0.05$. There is a significant difference on the mean retention test scores when compared among the three groups of digital media, $F(2,83)=5.857, p=0.05$. So, it can be concluded, there is a significant effect to the overall retention test when the visitors were using VR, Video or Web.

In order to determine which groups were contributing to this significant difference, a post hoc test using Tukey's HSD was conducted. First of all, when the VR group was compared to the Video group, it reveals a significant difference $(p=0.05)$ with the effect size of 1.835, but when compared to the Web group, it reveals a non-significant difference $(p>0.05)$. Secondly, when the Video group was compared to the VR group, it reveals a significant difference $(p=0.05)$, but when compared to the Web group, it reveals a non-significant difference $(p>0.05)$. Thirdly, when the Web group was compared to the VR group as well as the Video group, it reveals a nonsignificant difference ( $p>0.05)$.

These results show that the mean scores on both VR and Web as well as Video and Web are non-significant differences but the mean scores differ when VR is compared to Video. These findings contradict with the previous findings [17] that suggest there was no significant effect to the overall retention test if the visitors were using VR, Video or Web. Due to the evaluation system was setup in open settings; it is observed that participants were mainly disturbed by surrounding noise and activities. This disturbance may 
increase their cognitive workload that has been occupied on other tasks. During the session, participants need to do multitasking on VR navigation, to do the designated tasks, to focus on the content, and to learn history that was unfamiliar to them at the same time. The huge demand for brain processing would lead to fatigue and demotivate participants to further explore or digest new information. The term cognitive overload may apply to this situation and this is certainly not favourable [18], [19].

\subsubsection{Gender Effects on Retention Score}

Table 4 on the following page shows male (mean=5.57, SD=2.166) scored slightly higher than female (mean=5.36, SD=2.304). The independent ttest is used in which there are two conditions and different subjects have been used in each condition. The independent t-test was conducted to determine the effect of gender (male, female) on the retention test scores. For this analysis, equal variances are assumed as Levene's Test is not significant ( $p>0.05)$. In the main test, the two-tailed value of $p$ is 0.668 , which is greater than 0.05 so it is concluded that there is no significant difference between the mean of these two samples. Thus, male scored the retention test as equally as female scored the retention test. This complements previous findings by [20] that male and female were equally interested in using interactive digital media. However, male is found to be actively engaged and female is found to spend longer in using interactive digital media than its counterpart.

\subsubsection{Age Effects on Retention Score}

One-way analysis of variance (ANOVA) was conducted to identify the effect of age on the retention test scores. The distribution of age has been transformed to three specific groups of children, young adults, and adults. Table 4 depicts the descriptive analysis based on the new groups of age and the corresponding mean scores of the retention tests.

Table 4 Descriptive analysis on gender and age over retention

\begin{tabular}{clcc}
\hline Item & Classification & $\mathbf{n}$ & $\begin{array}{c}\text { Mean, } \mathbf{M} \\
\text { (Standard } \\
\text { Deviation, SD) }\end{array}$ \\
\hline \multirow{2}{*}{ Gender } & Yes & 42 & $5.57(2.166)$ \\
& No & 44 & $5.36(2.304)$ \\
Age & $<15$ & 16 & $3.44(1.861)$ \\
& $15-24$ & 54 & $5.81(2.057)$ \\
& 25 and above & 18 & $5.61(2.789)$ \\
\hline
\end{tabular}

It is found that the mean score for young adults 15 to 24 years old is the highest $(M=5.81, S D=2.057)$ and adults 25 years old and above scores second $(M=5.61, S D=2.789)$. The lowest mean score is children $(M=3.44, S D=1.861)$.

One-way analysis of variance was conducted to determine the effect of each group on retention test scores. The confidence interval used was $95 \%$ or 0.05 . This analysis assumed that the group variances are equal as $p>0.05$. There is a significant difference on the mean retention test scores when compared among the three groups of age, $F(2,85)=7.432$, $\mathrm{p}=0.001$. Post-hoc test was conducted to find which group did affect the mean retention test score. It is found that children have contributed to this significant difference with the effect size of 2.377 when compared to young adults and 2.174 when compared to adults.

Although previous museum studies found that interactive digital media is appealing to children [4], [11], [14] they did not reveal whether children did recall facts and figures, particularly the historical information. The nearest findings highlighted that children worked best at museums in learning bydoing such as reconstructing ruined buildings and completing pottery puzzles [4]. This missing bit is complemented by the findings of this study that children has difficulties to recall facts and figures from interactive digital media presumably because their lack of prior knowledge on structural elements [33]. This could be attributed to that not all children are digital native. However, the contributing factors of low retention among children may warrant further research.

\subsection{DISCUSSION AND CONCLUSION}

In this study, common demographic profiles are majority were students, more than three (3) years of computer experience and familiar with mouse and keyboard. All participants do not familiar with the cultural heritage site. Most participants have no idea of term 'virtual heritage' which indicate this kind of system is either new to them or rarely be encountered. It is also observed that majority participants were children below 15 and young adults from 15 to 24. Large amount of participation indicates children and young adults generally were attracted to use VR. The attraction of VR in museums is appealing to children and young adults, consistent with similar findings by [11] and the attraction is similar to studies of multimedia interactive applications reported in [20]. Although participation from older adults was less, observation reveals that they would pick the youngest or credible children in the group or family to represent them in the evaluation. However, when it comes to learning, children were unable to capture facts and figure as fast as the young adults. This learning process is consistent to those observation findings by [12] that 
found adults have higher level of engagement as they learnt faster due to their prior knowledge.

This study has performed retention test within its designated experimental time in which the retention may deteriorate over time. Thus, the facts and figures recalled by visitors at the time of study may not be recalled after certain span of time.

This study has determined the effects of three modes of digital media (virtual reality, video, and Web) on architectural heritage learning. It is found that there is a significant difference among these digital media on retention meaning that the use of digital media may affect architectural heritage learning to occur. Further analysis reveal that virtual reality has the lowest retention score and contributes to this significant difference when compared to video.

This study also has determined the demographics' effects of museum visitors on learning using interactive digital media. There is no significant difference between gender and retention scores. This suggests that male scored the retention test as equally as female scored the retention test. There is a significant difference among age and retention test and further analysis reveals that children has difficulties to recall facts and figures from interactive digital media [33]. However, low retention scores among children may warrant further research.

This study does not measure whether information acquired by visitors at the time of study is retained for certain span of time. Thus, a longitudinal study may be conducted to confirm the effects of interactive digital media on architectural heritage learning after a certain period of their visit to physical museum.

\section{Acknowledgement}

Our utmost gratitude goes to the Director of Perbadanan Muzium Melaka (PERZIM) for granting this study a place and hospitality. This study is funded by Ministry of Education Malaysia through Fundamental Research Grant Scheme.

\section{References}

[1] Falk, J. H. and Dierking, L. D. 2000. Learning From Museums: Visitor Experience And The Making Of Meaning. AltaMira Press.

[2] Pujol-Tost, L. and Economou, M. 2006. Evaluating The Social Context Of ICT Applications In Museum Exhibitions. In The e-volution of Information Technology in Cultural Heritage. Where Hi-Tech Touches the Past: Risks and Challenges for the 21st century. Proceedings of the 7th International Symposium on Virtual reality, Archaeology and Cultural Heritage, VAST2006. Greece: Eurographics, 2006. 219-228.

[3] Pujol-Tost, L. and Economou, M. 2009. Worth A Thousand Words? The Usefulness Of Immersive Virtual Reality For Learning In Cultural Heritage Settings. International Journal of Architectural Computing. 7(1): 157-176.

[4] Roussou, M. 2004. Learning By Doing And Learning Through Play: An Exploration Of Interactivity In Virtual
Environments For Children. ACM Computers in Entertainment. 2(1): 1-23.

[5] Michael, D., Pelekanos, N., Chrysanthou, I., Zaharias, P. Hadjigavriel, L. L. and Chrysanthou, Y. 2010. Comparative Study Of Interactive Systems In A Museum. EuroMed, M. loannides, Ed. Heidelberg: Springer- Verlag, 2010. 250-261.

[6] Froschaver, J., Merkl, A. D., M., and Goldfarb, D. 2013. Art History Concepts At Play With Thiatro. ACM J. Comput. Cult.Herit. 6(2): 15.

[7] Coenen, T., Mostmans, L., and Naessens, K. 2013. Museus: Case Study of A Pervasive Cultural Heritage Serious Game. ACM J.Comput. Cult. Herit. 6(2): 19

[8] Pujol-Tost, L. and Economou, M. 2007. Exploring The Suitability Of Virtual Reality Interactivity For Exhibitions Through An Integrated Evaluation: The Case of The Ename Museum. Online International Museology Journal. 4: 84-97.

[9] Forte, M., Pescarin, S., and Pujol, L. 2006. VR Applications, New Devices And Museums: Visitor's Feedback And Learning. A Preliminary Report. The E-Volution Of Information Technology In Cultural Heritage. Where HiTech Touches The Past: Risks And Challenges For The 21st Century. Spain: Eurographics. 64-69.

[10] Champion, E. 2011. Playing with the Past. Springer-Verlag, 2011 .Alzua-Sorzabal, M. Linaza, M. Abad, L. Arretxea, and A. Susperregui. Interface Evaluation For Cultural Heritage Applications: The Case Of FERRUM Exhibition. In The 6th International Symposium on Virtual Reality, Archaeology and Cultural Heritage, M. Mudge, N. Ryan, and R. Scopigno, Eds. 2005. 121-128.

[11] Podgorny, J. 2004. Studying Visitor Engagement In Virtual Reality Based Children's Science Museum Exhibits. Master's thesis, University of Chicago, June 2004

[12] Roussou, M. 2001. Immersive Interactive Virtual Reality In The Museum. Proc.of TiLE (Trends in Leisure Entertainment), June 2001.

[13] Kondo, T., Shibasaki, J., Arita-Kikutani, H., Manabe, M. and Inaba, R. 2007. Mixed Reality Technology At A Natural History Museum. Museums And The Web 2007. Proceedings, J. Trant and D. Bearman, Eds. Toronto: Archives and Museum Informatics, March 312007 , retrieved August 5, 2009 from http://www.archimuse.com/mw2007/papers/kondo/ kondo.html. [Online].

[14] Lazar, J., Feng, J. H. and Hochheiser, H. 2010. Research Methods in Human-Computer Interaction. United Kingdom: Wiley, 2010.

[15] Champion, E. M. 2006. Evaluating cultural learning in virtual environments. ad, Faculty of Engineering and Faculty of Architecture, The University of Melbourne, January 2006.

[16] Abubakar, J. A., Jahnkassim, P. S. and Mahmud, M. 2011. The Effects Of Interactive Versus Passive Digital Media On Museum Learning. International Conference on Computing and Informatics ICOCl2011, Bandung, Indonesia, June 8-10 2011. 400-406.

[17] Sharp, H., Rogers, Y. and Preece, J. 2007. Interaction Design: Beyond Human Computer Interaction. John Wiley and Sons, Ltd.

[18] Shneiderman, B. and Plaisant, C. 2010. Designing the User Interface: Strategies for Effective Human-Computer Interaction. Fifth, Ed. Pearson.

[19] Campbell, J., Stanley, C. and Gage, N. L. 1963. Experimental And Quasi-Experimental Designs For Research. No. 04; Q175, C3. Boston: Houghton Mifflin.

[20] Okazaki, S. and Hirose, M. 2009. Effects Of DisplacementReinforcement Between Traditional Media, PC Internet And Mobile Internet: A Quasi-Experiment In Japan. International Journal Of Advertising. 28(1): 77-104.

[21] Churches. 2008. Bloom's Taxonomy Blooms Digitally. Tech \& Learning 1.

[22] Krathwohl, D. R. 2002. A revision Of Bloom's Taxonomy: An Overview. Theory Into Practice. 41 (4): 212-218. 
[23] Blandford, A. 2013. Semi-structured Qualitative Studies. The Encyclopedia of Human-Computer Interaction. 2nd Ed.

[24] Preece, J., Sharp, H., and Rogers, Y. 2015. Interaction Design-Beyond Human-Computer Interaction. John Wiley \& Sons.

[25] Sharp, H. 2003. Interaction Design. John Wiley \& Sons.

[26] MacKenzie, S. and Soukoreff, R. W. 2003. Card, English, And Burr (1978): 25 Years Later. In CHI'03 Extended Abstracts On Human Factors In Computing Systems. 760761.
[27] Popovici, D. M., Querrec, R., Bogdan, C. M. and Popovici, N. 2010. A Behavioral Perspective Of Virtual Heritage Reconstruction. Int. J. Comput. Commun. Control. 5: 884891.

[28] Plowman, L. and McPake, J. 2013. Seven Myths About Young Children And Technology. Childhood Education. $89(1): 27-33$. 